\title{
COVID-19, tourism, and small islands in Indonesia: Protecting fragile communities in the global Coronavirus pandemic
}

\author{
Luchman Hakim
}

Department of Biology, Faculty of Mathematics and Natural Sciences, Brawijaya University, Malang 65145, East Java, Indonesia

Publication Information:

Received 23 April 2019, Accepted 5 May 2019, Available online 29 June 2020

DOI: $10.21463 /$ jmic.2020.09.1.08

\section{Abstract}

Small island communities are one of the critical groups with a high risk to the coronavirus disease (COVID-19) pandemic. The limitations of health systems and rapid growth of tourism are problems faced by local communities in small islands in the recent COVID-19 epidemic. This paper discusses the potentiality and issues of tourism and the COVID-19 threat in small islands. The iconic landscape and culture of Indonesian small islands led to significant tourism growth in these small islands. This situation opens opportunities for pathogens to spread within small islands. In the situation where the COVID-19 vaccine was not available, this article proposes four levels of action which are relevant to the protection of small islands and therefore contribute to the sustainability of the tourism industry in the small islands. These include: before pandemic, during the pandemic, post pandemic, and normal situation. The ability to design mechanisms postpandemic is crucial. Developing and enhancing health system management in small islands is important; moreover, spatial tourism destination planning should be integrated in tourism planning in small islands. Promoting and strengthening community support and participation is crucial to minimize pandemic threats. In the normal situation, promoting the best practice of tourist, community, and environmental relationships is important in small islands through ecotourism. Ecotourism stresses a high quality of tourism programs and tourist-host interactions within the carrying capacity of islands and therefore contributes significantly to minimize pandemic diseases.

\section{Keywords}

pathogens, pandemic, sustainable tourism destination, community resilience, community participation 


\section{Introduction}

The World Health Organization (WHO) has declared the coronavirus disease, known as COVID-19, a global pandemic. COVID-19 was first reported in Wuhan (China) in December 2019 and outbreaks have since been reported across the world, affecting countries in Europe, America, Asia, Australia, and Africa. In Southeast Asia, Indonesia has been reported as one of the countries with confirmed cases of COVID-19. By March 26, 2020, the WHO reported 1,796 cases from Malaysia, 1,045 cases from Thailand, 893 cases from Indonesia, 631 cases from Singapore, 109 cases from Brunei Darussalam, 707 cases from Philippines, 148 cases from Viet Nam, 96 cases from Cambodia, and 1 case from Timor Leste (World Health Organization, 2020).

In Indonesia, the origins of the spread of COVID-19 were initiated by the contact of one Indonesian female with her Japanese friend. The contact was reported on February 20, 2020 in Jakarta. The Japanese friend reported working in Malaysia and was confirmed positive for COVID-19. On March 3, 2020, the President of Republic Indonesia announced the first case of COVID-19 in Indonesia. Following this, the growth of reported COVID-19 cases increased significantly (Fig. 1). By April 13, 2020, the Ministry of Health Republic of Indonesia reported 4,557 CoVID-19 cases in Indonesia.

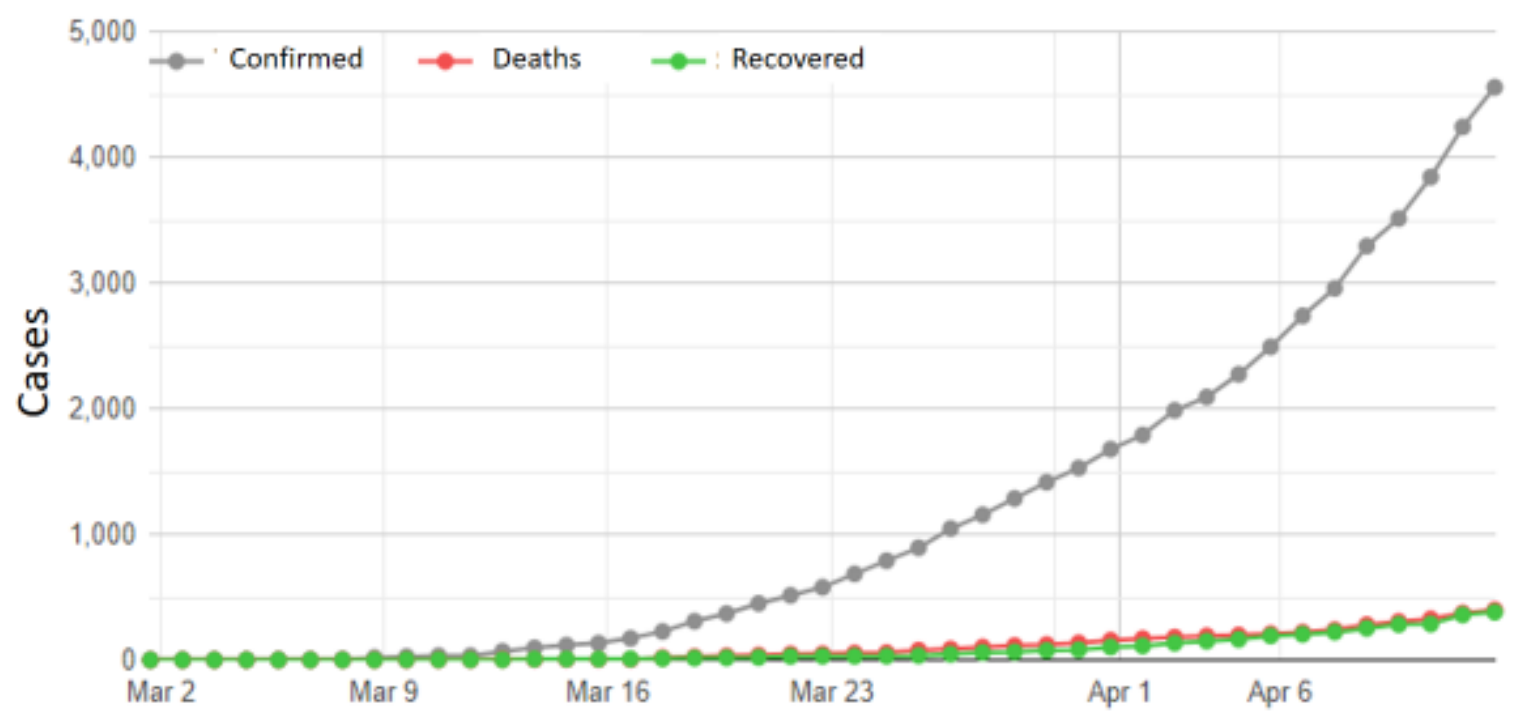

Fig 1. The growth of COVID-19 cases in Indonesia from February 2, the first report, to March 23, 2020. The first death case was reported on March 11, 2020.

By April 13, 2020, patients who were positive with COVID-19 were reported in 34 provinces, including: Aceh (5), BangkaBelitung (4), Bengkulu (4), Jambi (4), West Sumatra (67), North Sumatra (67), Riau (20), Riau Islands (21), Lampung (21), Banten (285), DI Yogyakarta (57), DKI Jakarta (2186), West Java (540), Central Java (203), East Java (440), West Kalimantan (13), East Kalimantan (35), Central Kalimantan (25), South Kalimantan (34), North Sulawesi (17), Southeast Sulawesi (16), South Sulawesi (223), West Sulawesi (5), Central Sulawesi (19), Gorontalo (1), North Maluku (2), Maluku (11), Bali (86), West Nusa Tenggara (37), East Nusa Tenggara (1), West Papua (2), and Papua (68). Researchers 
estimated that the number of provinces with COVID-19 cases would further increase. Without significant, effective, and comprehensive action against virus transmission, researchers estimated that COVID-19 would spread throughout the entire Indonesia archipelago.

To respond to the potential spread of COVID-19 in the Indonesia area, a significant action was released by the Indonesia government, provincial, regencies, and cities. Some offices, universities, and schools in areas with positive COVID-19 cases were closed. The prohibition and strict control of public activity were carried out to countermeasure the COVID-19 spread. Travel restrictions, practicing hand-hygiene, self-isolation and physical distancing, working from home, studying in-home, and promoting distance learnings were recommended to minimize virus transmission (https://www.kemkes.go.id/index.php; https://www.kemdikbud.go.id/main/. In Indonesia, local communities in small islands are critical groups in the recent COVID-19 pandemic. Local communities lack protection and rapid response mechanisms against such pandemic diseases. Small islands have a comparative lack of skilled human resources in the medical sector, which leads to poor community readiness to countermeasure pandemic diseases. Health facilities are often poor and in many cases not available. These factors lead to such communities being the most potentially fragile in the COVID-19 pandemic.

The spread of this pandemic disease is essentially crucial for tourism destinations (Yeoman, et al., 2006; Kuo, et al., 2008; Jamal \& Budke, 2020), especially in the case of the COVID-19 spread in small islands, which are visited by foreign tourists. The fact that small islands with pristine nature and unique culture are very interesting in the tourism industry leads to potential contact between local dwellers and tourists. This means that local dwellers in isolated islands are at a high risk for COVID-19 exposure. This paper aims to discuss the threats and framework for COVID-19 mitigation in small islands, which have been developed as a tourism destination. Tourism sectors though the activity and contact between tourists and the local communities in small islands, potentially contribute to the spread of pandemic disease. The framework is constructed from the recent situation of the COVID-19 pandemic in Indonesia, the socio-ecological status of small islands, and trend of tourism growth in small islands. We use secondary data to build a framework to countermeasure the COVID-19 pandemic to ensure the sustainability of tourism in small islands.

\section{Small islands in Indonesia}

The government of Indonesia lists 17,504 islands under its territory. About 16,000 islands are registered to the UN, with the remaining (about 1,448) islands left with a need to be validated and verified. The biggest islands include Sumatra, Java, Kalimantan, Sulawesi, and Papua. Most of the islands however are small. The eastern part of the Indonesia archipelago is an area with a high number of small islands. Indonesia is one of the biggest archipelago countries in the world.

Located in the tropical regions, all of the islands are characterized by tropical vegetation. The geological history of the island's chain establishment leads the Indonesian archipelago to be endowed by extraordinary species of flora and fauna. The fauna of Indonesia can be classified as Sunda lands fauna in the west (Sumatra, Java, and Kalimantan) and Australian fauna in the east. Some islands have endemic animals, including Rinca-Padar-Komodo Islands as a habitat for Varanus komodoensis (Van Oosterzee, 1997; Lohman, et al., 2011). 
The small islands in the Indonesia archipelago situated in tropical regions exhibit two seasons, i.e., rainy and dry seasons, with average temperatures that range from 25 to $32^{\circ} \mathrm{C}$. Small islands in Indonesia receive optimal sunlight, in which reducing pathogen growth is essential. Historically, scholars have observed that solar radiation can kill pathogens, especially influenza (Moan, et al., 2009; Juzeniene et al., 2010). Solar radiation has also been observed to be able to kill pathogens in water and therefore can contribute to the purification mechanism of natural waters (Calkins, et al., 1976). The ability to kill pathogens leads to the application of solar pasteurization to provide the drinking water for cheap (Pejack, 2011).

Small islands in Indonesia are home to numerous tribal communities and ethnic minorities. Many communities in the small islands were identified as communities with a high level of indigenous knowledge, which is important to ensure a sustainable community living system in island environments. The communities in the small islands in Indonesia rely on the agricultural and fisheries sectors. Generated income has been reported to be relatively low. The lack of jobs on the small island often leads the local dwellers to find jobs in big cities. Some people work in Malaysia, Taiwan, Singapore, Saudi Arabia, and other countries as an Indonesian migrant worker (https://www.indonesia-investments.com).

Small islands in Indonesia are close to some crucial issues related to community health (Rijanta, 2005; Girsang, 2009; Tebay, 2011; Massie \& Kandou, 2013; Firdaus et al., 2016, Susilawaty et al., 2016). Access to formal education supporting economic facilities and health systems is limited. Local dwellers in small islands are often isolated and face limited access to health facilities (Table 1) and furthermore can also have comparatively poor knowledge and skill. Consequently, the dependency of local communities on medical plants is high, and in many areas shamanism is still practiced on small islands and is a common approach to treat disease.

Table 1. Crucial conditions of small islands in Indonesia relevant to the community health and pandemic

\begin{tabular}{|l|l|}
\hline \multicolumn{1}{|c|}{ Aspects } & \multicolumn{1}{c|}{ Remarks } \\
\hline Level of education & Mostly not finished elementary school. The number of elementary and juniors school is limited \\
\hline Households income & Agriculture and fisheries \\
\hline Sanitation & Basically worse, especially in a fisherman village \\
\hline Health facility & Facility limited, available in some islands, community health clinic (PUSKESMAS) in poor facility support \\
\hline Health workers & Lack of doctor and nurse \\
\hline Freshwater & Freshwater often limited; some community bring fresh water from the nearest island with the water spring \\
\hline Electricity & Electricity often not available. Bioenergi was based from firewood \\
\hline Drugs material & Drugs materials were extracted from known medical plants among community \\
\hline
\end{tabular}




\section{Small islands and tourism}

In Indonesia, tourism has been identified to contribute significantly in the national economic earning. Tourism is also reported being able to support local economic growth, providing jobs for the local community, and contributing to regional development. From 2017 to 2019, the contribution of Malaysia, Singapore, and China in international tourist arrivals to Indonesia was statistically significant. Data shows that in January 2020 the number of tourists from Malaysia was about 206,532 tourists, from Singapore was 138,625 tourists, and from China was 181,281 tourists. Jakarta and Bali is the most visited area regarding tourist destinations (http://www.kemenparekraf.go.id/).

The recent growth of nature-based tourism sectors leads to numerous pristine ecosystems (i.e., mountains, savanna, small islands) being explored and promoted as nature-based tourism destinations. Considering the significance tourism contribution to the national economic earning, central governments recently declared massive tourism destinations in ten areas, namely Lake Toba in North Sumatra, Tanjung Kelayang in Bangka Belitung, Kepulauan Seribu in Jakarta, Tanjung Lesung in Banten, Borobudur Temple in Central Java, Bromo Tengger Semeru in East Java, Morotai in North Maluku, Wakatobi in Southeast Sulawesi, Labuan Bajo in East Nusa Tenggara, and Mandalika in Lombok. The government also provides specific attention to the acceleration of the five super-priority destinations, including Lake Toba, Borobudur Temple, Lombok Island, Labuan Bajo, and Manado Bitung-Likupang islands. From these declared sites, small islands were the crucial target for development, i.e., Tanjung Kelayang in Bangka Belitung, Kepulauan Seribu Morotai in North Maluku, Wakatobi in Southeast Sulawesi, Labuan Bajo in East Nusa Tenggara, and Mandalika Manado Bitung-Likupang islands (http://www.kemenparekraf.go.id/).

Small islands in Indonesia are famous for being tourism destinations. Small islands offer spectacular and unspoiled landscapes, many of which are habitats for endemic and critically endangered species. The waters are surrounding small islands in Indonesia are a harbor for numerous marine creatures, ranging from invertebrates to vertebrates. Many vertebrates live in small island waters, including sea turtles. The biodiversity of coral and coral fish is significantly rich. Additionally, diving and snorkeling are a favorite for special interest tourism programs (Walpole \& Goodwin, 2000; Hakim et al., 2012).

In the limitation to access small islands as a tourist, the yacht race offers opportunities to visit remote islands. Sail in Indonesia has become a particular personal interest for tourists in Indonesian waters. The history of recent Sail Indonesia originates from "Darwin to Dili Yacht Race" in 1973. In 2001, it was renewed as the "Darwin Bali Yacht Race" with routes to Darwin (Australia)-Denpasar (Bali, Indonesia). In order to promote tourism beyond Bali, in 2009, the yacht race was programed according to the end destination of race in Indonesia (Fig. 2). The Sail Banda (2010), Sail WakatobiBelitong (2011), Sail Morotai (2012), Sail Komodo (2013), Sail Raja Ampat (2014), Sail Tomini (2015), Sail Selat Karimata (2016), Sail Sabang (2017), Sail Moyo-Tambora (2018), and Sail Nias (2019) exist. As a response to the COVID-19 pandemic, Sail Indonesia 2020 was canceled (http://www.sailindonesia.net/home/home.php). The yacht race increases the potential of local communities in remote islands of being exposed to this infectious disease. Tourist contact with local dwellers during docked and island exploration opens opportunities for pathogens transmission. In the situation where the health system against contagious disease pandemic is poor, decisions such as the canceling of Sail Indonesia 2020 is vital. 


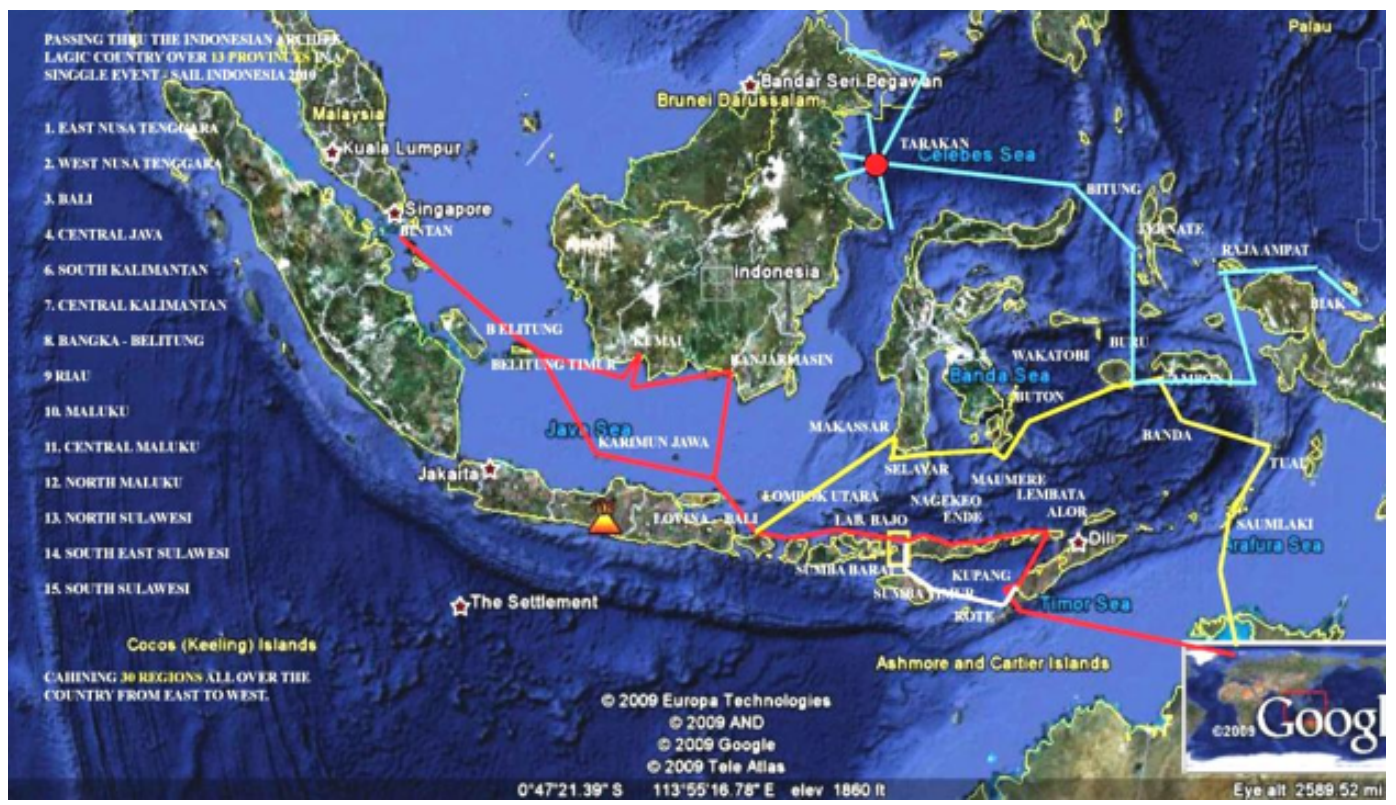

Fig 2. Indonesian waters are a playing ground for the Yacht Race

Recent rapid development in particular islands provides additional attractions. This is especially observed in islands that are targeted for tourism development. For instance, the development of the Mandalika resort in the Lombok Islands with numerous tourists as a world-class facility. The development of Labuan Bajo becomes a crucial key to the potential massive tourist arrivals in Nusa Tenggara. Nusa Tenggara recently became the favorite for nature and culture-based tourism destinations. These developments demonstrate serious consequences, including an increase of tourist numbers in limited areas, changes of environmental problems, and potential socio-economic problems. In other words, opportunities exist for disease spread. Tourist behaviors are frequently identified as contributing to the spread of disease, especially HIV/AIDS (Wright, 2003; Santos \& Paiva, 2007).

Access systems to many small tourism islands in Indonesia, however, is problematic because of the lack of the integrative island-entry monitoring systems, especially in eastern Indonesia. The combination of a poor system, poor human resources, and a poor health system leads to many islands being easily accessible by people with pandemic pathogens, including COVID-19, without proper recognition.

\section{How COVID-19 has affected Indonesia's small islands tourism destinations}

Understanding the mechanism and impact of COVID-19 pandemic in small islands tourism destinations is important. Tourists are able to access small islands through some entry gates. Presently, the airport and seaports are the main gateway to access island tourism destinations. Small islands as a tourism destination have airports, including international airports, domestic airports, and pioneer airports. Seaports also exist, in which they often share with 
fisherman ports. Tourists can access small islands through these two entry gates, in order to access numerous natural and cultural tourism attractions. However, many small islands remain poor regarding facility access. Only the 'simple fisherman port' was available with limited facilities.

To date, comprehensive quantitative data on the impact of COVID-19 pandemic to tourism sectors in Indonesia is poor. However, many newspaper report that impact is significant. Traveling is one of the main mechanisms for pathogens' spread. Prior to the COVID-19 pandemic, flight traffic to Bali, Lombok and Labuan Bajo has been reported as significant. The recent COVID-19 pandemic, however, lead Indonesian government and airlines to reduction (and stopping) of flight traffic to numerous destinations; Bali being the most affected island (https://bali.bisnis.com/).

According to tour \& travel agencies, tour programs to visit tourism attraction dropped sharply from January to April, 2020 , with tourism programs (to visit numerous natural attractions in remote villages) being prohibited to minimize pathogens' spread. Many natural and rural areas as tourism destinations were closed. Many transportation company services have consequently closed due to the drop in travel demand. A similar situation was found in Lombok Islands and Labuan Bajo (https://www.thejakartapost.com/).

In Bali, the decrease of tourist arrivals has significantly contributed to the tourism accommodation. Bali has already closed at least $96 \%$ hotels since April 2020, and many homestay and community owned lodge have suffered a drastic activity. Homestay and community owned lodges are recently being more impacted than hotels. There has been dramatic reduction in food and beverages business. Many bars, restaurants and cafés have closed in response to the drops of tourist. Drivers, tour planners and tourist guide lost their jobs. Some SMEs industry related to tourism have been reported to have collapsed. Many SMEs have been reported laid off of worker temporarily or permanently (https://www.thejakartapost.com/; https://bali.bisnis.com/).

\section{Managing tourism in small islands against COVID-19}

In a pandemic situation, national tourist target achievement is not important, both in terms of tourist numbers and revenues generating from tourism sectors. Global and national policy have declared that ensuring the future of humankind is important. Additionally, finding a solution to countermeasure the pandemic is also necessary. So far, no protocols exist to protect COVID-19 threats and attract tourists to destinations in Indonesia, especially in small islands.

Indonesia's small islands can adapt or cope from the COVID-19 pandemic through a comprehensive approach. Four levels of action are proposed, which are relevant to the protection of small islands and therefore contribute to the sustainability of the tourism industry in the small islands. These levels of action include the following: before pandemic, during the pandemic, post pandemic, and normal situation (Fig. 3).

\section{Before pandemic}

Preparedness is the first step is crucial in pandemic mitigation and management in small islands. The crucial action in this first steps includes: island community and stakeholder coordination, define and establish standard operational procedure, and the training of volunteers. The goals of the preparedness are to increase community, local government 
and stakeholders in small islands with the intention to: (1) strengthen the capacity and capability of communities in small island to develop a preliminary preparedness plan, (2) increase the capacity and capability of communities in small islands to cope with pandemic disaster situations.

\section{During pandemic}

Island lockdown seems to be a crucial strategy to protect fragile communities in small islands. Islands lockdown can be considered as an immediate response against COVID-19 threats. With relation to small islands, a lockdown can be implemented by closing ports or airports from people's movements, especially tourists. Developing a preventive scenario should build upon multi-stakeholders, especially stakeholders in the tourism industry. However, the potential problems result in limitations in coordination among governments, stakeholders, and local communities (Jamal \& Budke, 2020). In small islands in Indonesia, the major limitation of health support includes the following: (1) lack of health facilities, (2) lack of health workers with required skill and capability, especially in an emergency, and (3) lack of drugs/vaccines and medical materials. This will affect the ability to minimize COVID-19 spread. Without the health system support and with a poor quarantine, a fast COVID-19 spread may occur (Khan, et al., 2020).

Travel is the most important mechanism for virus transmission, including COVID-19. Previous reports confirm that a relationship between traveling, infections, transmission, and the spread of pathogen viruses exists (Monath \& Cetron, 2002; Wright, 2003; Santos, \& Paiva, 2007; Ala'a, \& Albattat, 2019). In the situation where drugs and vaccines against COVID-19 are not available, stopping traveling and recreation activities are important. There will be significant impact on transportation policy to access small islands. The positive impact will include reduce pandemic spread risk and protect local islands inhabitants from infections. The potential problems however, include disturbance in logistics (including food, drugs and health equipment) are crucial to support a coping strategy and mechanism against diseases. In such situations, transportation to support coping strategies should allow and accommodate following standard operational procedure to minimize potential pathogens introduction and spread.

Promoting indigenous knowledge of local dwellers in small islands against pandemic diseases is important. In the situation of a pandemic, fostering those who died properly is considered as one of the mechanisms against a pandemic. The ethnobotanical knowledge of the local community is important to provide a mechanism in consumption of foods and beverages with high levels of nutrition, vitamins, and active compounds, which are important against pathogens (Gaisbauer \& Langosch 1990; Chan, 1995; Rauma et al., 1995; Josling, 2001). Local communities in small islands often consume traditional beverages to maintain community health, including increasing body immunity against pathogens. These become the cultural approach to increase community health endurance.

Community participation has been recommended as one of the effective mechanisms to combat infectious disease pandemics (Chawla et al., 2009). In such a case, local system leadership is especially important in chaos situations, where local communities in the panic situation miss broader communication. Optimizing local institutions and informal local leaders seems effective in supporting preventive scenarios. 


\section{Post pandemic}

The World Health Organisation (WHO, 2009), in the case of the Avian flu pandemic, defined post-pandemic as the "level of influenza activity have returned to the levels seen for seasonal influenza in most countries with adequate surveillance." The WHO is stressing the crucial program and action "to maintain surveillance and update pandemic preparedness and response plans." The evaluation was required to provide data and information for countries and other stakeholders to develop further anticipation to prepare communities against future pandemics.

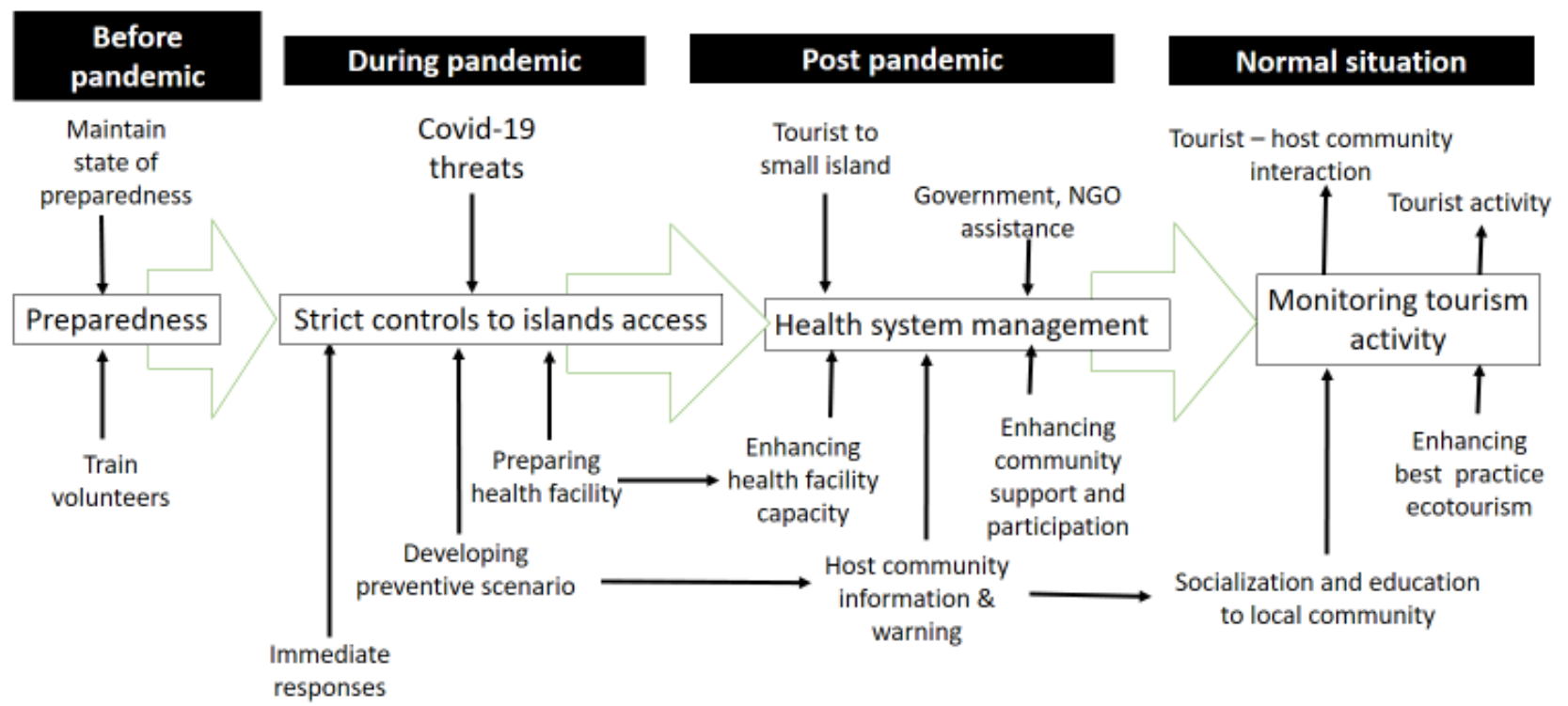

Fig 3. Framework for protecting the local community in small islands against COVID-19.

Enhancing community health immunity is important, and principally, it is relevant to the food conception pattern. In such a situation, vegetables, fruits, and spices are essential to consume to increase body immunity against diseases. Relevant to these issues, optimizing the role of home gardens to provide high-quality foods is important in small islands. Home gardens contain numerous biodiversity, which is important to provide food, staple foods, vegetables, and spices.

The structure and composition of home gardens in small islands are often unique. Problems, however, many home gardens with high number of biodiversity were decrease both in quantity and quality. A decrease in quantity, especially related to the space needs to facilitate tourism growth. Quality related to the (1) decrease of local plant species number, (2) increase of exotic plant species, and (3) decrease plants with active compounds. Revitalization of home gardens as a habitat for numerous medical plants was important with the objective provides biomaterial against pathogens pandemic.

In the post-pandemic phase, controlling tourist arrivals and activity in small islands is important. Two important issues exist that should be highlighted. First, managing tourist and host community interaction is important. Tourist and host community contact is one of the easiest mechanisms for pathogen transmission. Second, monitoring tourist activity in 
small islands is crucial. Some tourist activity contributes to pathogen spreads and health decreases. Free sex, prostitution, drugs, and alcohol are among the severe impacts that are related to the local community health.

\section{Normal situation}

In the normal situation, establishing programs related to socialization and education to the local communities is important. Enhancing the best practice of ecotourism is proposed. The crucial issue of tourism in small islands is the potential mass tourism in limited space and resources. Promoting ecotourism will allow more rational and strategic options. Mass tourism leads to a bulk number of tourists in a limited area. Therefore, this creates a high possibility of pathogen transmission. Mass tourism produces more waste and pollutants, and in many cases, it is beyond the capacity of destination to clean up pollutant. The benefits of ecotourism in reducing pandemic diseases can potentially come from several strategic issues (Table 2).

Table 2. Contribution of ecotourism to pandemic disease mitigation in small islands

\begin{tabular}{|l|l|}
\hline $\begin{array}{l}\text { Some aspects related } \\
\text { to ecotourism }\end{array}$ & \multicolumn{1}{|c|}{ Contribution in pandemic disease mitigation } \\
\hline Carrying capacity & $\begin{array}{l}\text { Promoting carrying capacity to control visitor numbers and massive tourism development that are dangerous to the environment } \\
\text { and local community. Avoid bulk visitor and reduce rapid pathogens transmission risk }\end{array}$ \\
\hline $\begin{array}{l}\text { Fund for community } \\
\text { and conservation }\end{array}$ & $\begin{array}{l}\text { Fund generating from ecotourism goes to the community to build health facilities, education, and promoting conservation to } \\
\text { support community health }\end{array}$ \\
\hline $\begin{array}{l}\text { Appreciate to local } \\
\text { food }\end{array}$ & $\begin{array}{l}\text { Consume local foods and beverages. Promoting local receipt with high nutrition and vitamins to enhance body health and } \\
\text { immunity }\end{array}$ \\
\hline $\begin{array}{l}\text { Respect to local } \\
\text { culture }\end{array}$ & $\begin{array}{l}\text { Decrease hedonic life style, learn different culture for better future living in biosphere, provide opportunities for local community } \\
\text { to continuous local culture and knowledge in less border words }\end{array}$ \\
\hline Local employment & Minimize employing foreign workers, who are potentially pathogens carriers \\
\hline $\begin{array}{l}\text { Environment } \\
\text { management }\end{array}$ & Improving sanitization \\
\hline
\end{tabular}

Threats to island chains because of the COVID-19 pandemic results in a strong argument to establish proper spatial tourism planning with health system support facilities. It is especially relevant to the development of many small island as world-class tourism destination standard, as recently planned and developed in Indonesia. So far, programs to improve health facilities receive little attention. The focus of destination development often includes establishing massive tourist accommodation, attraction, and accessibility infrastructure. Continuous improvement of the health system in small islands is important, and community participation to establish proper situations to minimize the next pandemic is important.

As mentioned above, the small islands in Indonesia lack skilled human resources and have numerous health limitations against pandemic disease. The issues of health and pandemic disease threats to small island tourism destination to date are emerging in discussions of in tourism development planning documents. In Indonesia and countries with a high number of islands, the recent challenges concerning COVID-19 has provided new experiences for future tourism planning in small islands. In small island tourism planning, ensuring local community health and ability to cope pandemic disease is very important. 


\section{Conclusion}

Local dwellers in small islands in Indonesia are one of the high-risk groups to the COVID-19 pandemic. Poor health facilities and potential exposure to the virus (due to tourist visitors to small islands) have become crucial aspects to the threat of the pandemic. Tourism sectors potentially contribute to the spread of the COVID-19 pandemic in small islands tourist destination chains. In the recent situation where COVID-19 spreads very quickly and vaccines to counter viruses still not being available, protecting small islands is consequently paramount. A lockdown may be a rational strategy to protect communities in small islands, while preventive scenarios were continuously performed, and medical facilities were continuously prepared and improved. The post-pandemic is the crucial phase, in which significant action needs to be well planned. In a normal situation, the control of tourism is still required. Promoting ecotourism is a rational action to be implemented in small islands.

\section{References}

Ala'a, A., Albattat, A., 2019. Current Issue in Tourism: Disease Transmission as a Potential Risk for Travellers. Review of Integrative Business and Economics Research, 8, 103-114.

Calkins, J., Buckles, J.D., Moeller, J.R., 1976. The role of solar ultraviolet radiation in 'natural' water purification. Photochemistry and photobiology, 24(1), 49-57.

Chan, M.M.Y., 1995. Inhibition of tumor necrosis factor by curcumin, a phytochemical. Biochemical pharmacology, 49(11), 1551-1556.

Chawla, R., Sharma, R.K., Madaan, D., Dubey, N., Arora, R., Goel, R., Singh, S., Kaushik, V, Singh, P.K., Chabbra, V., Bhardwaj, J.R., 2009. Mitigation approaches to combat the flu pandemic. Journal of global infectious diseases, 1(2), 117-130.

Firdaus, A.M., Pelupessy, J.M., Tampubolon, J.R., 2016. Strategi Penyelesaian Masalah Sosial Ekonomi Masyarakat Pesisir di Kepulauan Banda Neira, Kabupaten Maluku Tengah. Jurnal Sosial Ekonomi Kelautan dan Perikanan, 11(1), 55-74.

Gaisbauer M., Langosch A., 1990. Raw food and immunity. Fortschr Med. 08(17): 338-340.

Girsang, W., 2009. Strategi Pengentasan Kemiskinan di Pulau Kecil di Propinsi Maluku. Agrikultura, 20(3): $176-184$.

Hakim, L., Soemarno, M., Hong, S.K., 2012. Challenges for conserving biodiversity and developing sustainable island tourism in North Sulawesi Province, Indonesia. Journal of Ecology and Environment, 35(2), 61-71.

Jamal, T., Budke, C., 2020. Tourism in a world with pandemics: local-global responsibility and action. Journal of Tourism Futures. Article in Press.

Juzeniene, A., Ma, L.W., Kwitniewski, M., Polev, G. A., Lagunova, Z., Dahlback, A., Moan, J., 2010. The seasonality of pandemic and nonpandemic influenzas: the roles of solar radiation and vitamin D. International Journal of Infectious Diseases, 14(12), e1099-e1105.

Moan, J., Dahlback, A., Ma, L.W., Juzeniene, A., 2009, Influenza, solar radiation and vitamin D, Dermatoendocrinol, 1: $307-30$.

Josling, P., 2001. Preventing the common cold with a garlic supplement: a double-blind, placebo-controlled survey. Advances in therapy, 18(4), 189-193.

Khan, S., Siddique, R., Ali, A., Xue, M., Nabi, G., 2020. Novel coronavirus, poor quarantine, and the risk of pandemic. Journal of Hospital Infection. Article in press. 
Kuo, H.I., Chen, C.C., Tseng, W.C., Ju, L.F., Huang, B.W., 2008. Assessing impacts of SARS and Avian Flu on international tourism demand to Asia. Tourism Management, 29(5), 917-928.

Lohman, D.J., de Bruyn, M., Page, T., von Rintelen, K., Hall, R., Ng, P.K., Shih, H.T., Carvalho, G.R., von Rintelen, T., 2011. Biogeography of the IndoAustralian archipelago. Annual Review of Ecology, Evolution, and Systematics, 42. 205-206.

Massie, R.G., Kandou, G.D., 2013. Kebutuhan Dasar Kesehatan Masyarakat di Pulau Kecil: Studi Kasus di Pulau Gangga Kecamatan Likupang Barat Kabupaten Minahasa Utara Provinsi Sulawesi Utara. Buletin Penelitian Sistem Kesehatan, 16(2). 176-184.

Monath, T.P., Cetron, M.S., 2002. Prevention of yellow fever in persons traveling to the tropics. Clinical infectious diseases, 34(10), $1369-1378$.

Pejack, E., 2011. Solar pasteurization. In Drinking Water Treatment (pp. 37-54). Springer, Dordrecht.

Rauma, A. L., Törrönen, R., Hänninen, O., Verhagen, H., Mykkänen, H., 1995. Antioxidant status in long-term adherents to a strict uncooked vegan diet. The American journal of clinical nutrition, 62(6), 1221-1227.

Rijanta, R., 2005. Insularitas dan Keterbelakangan Ekonomi Wilayah menuju Model Konseptual Perkembangan Wilayah Pulau Kecil di Indonesia. Majalah Geografi Indonesia, 19(2).103-120.

Santos, A.D.O., Paiva, V., 2007. Vulnerability to HIV: tourism and the use of alcohol and other drugs. Revista de Saúde Pública, $41,80-86$.

Susilawaty, A., Amansyah, M., Nildawati, N., 2016. Kerentanan Ketersediaan Air Bersih di Daerah Pesisir dan Pulau-Pulau Kecil Sulawesi Selatan Indonesia. Al-sihah: The Public Health Science Journal, 8(2). 194-203.

Tebay, S., 2011. Kondisi sosial ekonomi dan budaya masyarakat pulau-pulau kecil sebagai suatu realitas - Studi Kasus Kepulauan Raja Ampat. Proseding seminar Pengembangan Pulau-Pulau Kecil 2011, 177-186.

Van Oosterzee, P., 1997. Where worlds collide: The Wallace Line. Ithaca: Cornell University Press.

Walpole, M.J., Goodwin, H.J., 2000. Local economic impacts of dragon tourism in Indonesia. Annals of tourism research, 27(3), 559-576.

World Health Organization, 2009. Pandemic Influenza Preparedness and Response: A WHO Guidance Document. Geneva: World Health Organization; 2009. 4, THE WHO PANDEMIC PHASES. https://www.ncbi.nlm.nih.gov/books/NBK143061/

World Health Organization, 2020. Coronavirus disease 2019 (COVID-19) Pandemic: https://www.who.int/emergencies/diseases/novelcoronavirus-2019.

Wright, E.R. (2003). Travel, tourism, and HIV risk among older adults. Journal of acquired immune deficiency syndromes (1999), 33 , S233-7.

Yeoman, I., Page, S., Connell, J., Walker, L., Munro, C., 2006. An influenza pandemic: what it could mean for Scottish tourism. Quarterly Economic Commentary, 30(4), 47-54. 